\title{
Viewing Indonesian Cultural Identity Through Korean Vlogs
}

\author{
Nurul Laili Nadhifah ${ }^{1}$, Arcci Tusita ${ }^{2}$, Sri Herminingrum ${ }^{3}$ \\ \{lely_n@ub.ac.id ${ }^{1}$; arcci.tusita@gmail.com² ${ }^{2}$,hermien_18@ub.ac.id $\left.{ }^{3}\right\}$ \\ Universitas Brawijaya, Indonesia ${ }^{1,2,3}$
}

\begin{abstract}
It is interesting that many Koreans talk about Indonesia, which is the reason that some Koreans create vlogs about Indonesian culture. The growing number of Korean youtubers that talk about Indonesia is the reason for this research, which aims to analyze: 1). How Korean youtubers describe Indonesian cultural identity through Korean's point of view, against Western's stereotypes about Eastern; and 2). How those youtubers participate in preventing the spread of Covid-19 through their vlogs. Self-orientalism is applied as the main theory, where Eastern placed themselves as 'the other' in seeing other Eastern, which purpose is to earn a place in a system dominated by Western. It could also be used to construct one's cultural identity, claiming cultural authenticity by using Western's stereotype which is already familiar for others. This research is a qualitative descriptive research, analyzing the narrations, comments, and dialogues found in the vlogs about the description of Indonesian cultures as data. Discussion focused on how Koreans see Indonesian cultures through their point of view. It also aims to see how those youtubers play an important role in preventing the spread of Covid-19 by applying Fiske's vertical intertextuality in analyzing the vlogs and the comments by the audiences.
\end{abstract}

Keywords: Vlog, Self-orientalism, Cultural Identity, Vertical Intertextuality, Covid-19, Indonesia, South Korea

\section{Introduction}

Seeing how K-Pop, or what is usually known as hallyu, really becomes popular all over the world, many Indonesians are interested in knowing more about Korean culture in general. Through internet, the world is familiar about hallyu 1.0 (K-drama), hallyu 2.0 (K-pop music), hallyu 3.0 (K-culture), and the newest one is hallyu 4.0 (K-style). Hallyu is one of the means that facilitate people from different countries to communicate with each other. The spread of hallyu and fans' different ways of interpreting the meanings cause many glocalization of cultural products and various ways of representing fans' cultural identity which are quite interesting to be analyzed. However, this writing focuses more on how Koreans see Indonesians through their own point of view.

As it is already known, many Indonesians are attracted in learning about Korean Culture, thanks to hallyu. Nevertheless, it seems that not only Indonesians become really eager in studying more about Korean culture, but also Korean people nowadays start to notice Indonesia and its unique culture. Indonesian people - who are fans of Korean culture - learn about hangul or Korean language, participate in some Indonesia-Korea events like festivals and others, buy some Korean products or the hybrid versions of them, and they even visit South Korea. In fact, on the other hand, since many of those Indonesians then manage to gain some Korean friends 
and communicate with them, many of Koreans start to pay attention to Indonesia as well. Not only big Korean agencies like SM Entertainment that pay more attention to Indonesia because of the profit that they gain from Indonesians, but also many Koreans make an effort to learn Indonesian language, are quite eager to learn about Indonesian local culture and share them through their vlog or YouTube accounts because they are genuinely interested with the uniqueness of Indonesia. This reason is the one that inspire this research to be done.

Those Korean Youtubers, somehow, do a great job in promoting Indonesia to other people -especially Koreans--. Their vlogs are also being an effective way to remind Indonesians themselves with their own culture. Moreover, since those Youtubers are Koreans, somehow, they gain plenty of fans who actually are Indonesia K-Pop fans. By doing this, in some way those fans try to negotiate their identity as K-Pop fans in the form of consuming online popular culture. Not only those K-Pop fans want to reconstruct the K-Pop itself into Indonesian local culture, but also those Korean Youtubers try to put their videos into Indonesian taste since the beginning.

There are three famous Korean Youtubers that often upload these kind of videos, Bandung Oppa, Noona Rosa, and Hari Jisun. This research analyzes their videos related with the problem of the study. Those youtubers are chosen among other Korean youtubers for the number of their subscribers - which are dominated by Indonesians --and the content of their vlogs which are mostly about Indonesian culture or Indonesian products.

Nevertheless, it should be understood that those videos are still made through Korean's point of view, means that Indonesian local culture here is seen by people who have different culture and value. Moreover, there are some possibilities that somehow their way of picturize Indonesian culture is affected by Western's stereotype toward Eastern. That is why, the first question of this research is how those three Youtubers explain about Indonesians' cultural identity through Koreans' point of view, furthermore, against the Western's stereotypes about Eastern, which will be analyzed by applying self-orientalism theory. The second question of this research is actually related with the condition nowadays, it is about how those Youtubers play any significant role in preventing the spread of Covid-19 through their vlogs, which will be analyzed using Fiske's intertextuality.

\section{Conceptual Framework}

Self-orientalism theory is applied to answer the first question. Unlike orientalism which analyzes the relation between East and West of "self" and "other", self-orientalism concentrates more on how East sees another one, while in some cases is influenced by Western's stereotype about East. Stiffler [1] also stated in his research that self-orientalism can be applied to construct a certain cultural identity, by using certain stereotype from Western that is already familiar, to reach what they call as cultural authenticity. Since this research is about how South Korea Youtubers see Indonesia's cultural identity through their point of view, this theory is seen as the most suitable one to apply.

Fiske [2], in his book entitled Television Culture: Popular Pleasures and Politics stated that "the theory of intertextuality proposes that any one text is necessarily read in relationship to others and that a range of textual knowledges is brought to bear upon it". There are two kinds of intertextuality, horizontal intertextuality and vertical intertextuality. Vertical intertextuality is relation between primary, secondary, and tertiary texts, which makes it chosen as the approach to apply to answer the second question. 


\section{Research Method}

This research is done by analyzing vlogs or videos by three famous Youtubers from South Korea: Bandung Oppa, Noona Rosa, and Hari Jisun. They are chosen for both their fame among Indonesian's viewers and their Youtube contents which mostly talk about Indonesian's culture and Indonesians' life in general, even their descriptions in their accounts use Indonesian language. Bandung Oppa, by using Indonesian language, stated in his description that he is a Korean who loves Indonesia and Bandung. He mentioned that Indonesia makes him happy which urges him to creates videos for Indonesians. He already gained $888 \mathrm{~K}$ subscribers with $77,131,523$ views from his 324 videos. Noona Rosa with $763 \mathrm{~K}$ subscribers and 91,929,802 views from her 175 videos mentioned in her description using Indonesian language that she is a Korean girl who used to learn Indonesian and stayed in Indonesia for a while. The last one is Hari Jisun, who already posted 400 videos and has 2,83 M subscribers with 530,861,841 views, described herself as "cewek korea yang cinta Indonesia" or Korean girl who loves Indonesia.

This research analyzed 11 (eleven) videos in total, which are three of them were taken from Bandung Oppa's account, the other three were from Hari Jisun's, and the rest were taken from Noona Rosa's Youtube account. Those videos were selected as they were seen related with the issues analyzed in this research.

\section{Result and Findings}

\subsection{Indonesian Traditional Culture}

There is a historical similarity between Indonesia and South Korea that underlies solidarity in interpreting their identity as Eastern people, one of which is the shared memory of Japanese colonial experience as stated by Huat and Iwabuchi [3]. In addition, Cheng [4] states that cultural proximity is another aspect that creates similarities in narrative about "East" between South Korea and Indonesia. In this context cultural proximity is defined as the close relationship between two cultural positions is indelible. The vlogs of three South Korean YouTubers, Hari Jisun, Noona Rosa and Bandung Oppa uploaded on the YouTube platform illustrate this phenomenon. The three South Korean YouTubers who are fluent in Indonesian articulate a narrative about Indonesian culture - traditional and popular - from the perspective of fellow Eastern people by introducing and comparing Indonesian culture with South Korean culture.

There are several aspects of local/typical Indonesian culture that the three Korean YouTubers raise in their contents, including food, place and way of eating, Javanese language, traditional medicine, the system of living in society and work ethic. It is interesting to further investigate the narration built in their vlogs because by raising the narrative of the authenticity of Indonesian local culture in YouTube contents, these South Korean YouTubers offer a different perspective in discussing and perceiving modernity. Modernity is not always associated with the West, but also Non-Western. In this case, they raise a peripheral culture and are juxtaposed with global culture in social media platforms with a global audience. That is, modernity does not merely follow the categories offered by the West, instead, modernity is a universal set of problems to which there can be different, authentic responses, dislocated in time and place [5]. 


\subsubsection{Indonesian Food, Place and Ways to Eat}

Food, both Indonesian and Korean specialties, is the most common theme in South Korean Youtuber vlog uploads. This is very common, because food can reveal various kinds of information, such as the culture and identity of a society. Fischer et al. [6] asserts that "food not only nourishes but also signifies". Food is not only something that is consumed by humans, but is also a cultural product that is embedded in a wider social and cultural structure and is manifested in the practice of people's lives.

In a video upload, Noona Rosa specifically introduces and discusses traditional market snacks/cakes when she and her friends go to the Museum Angkut in Batu City.
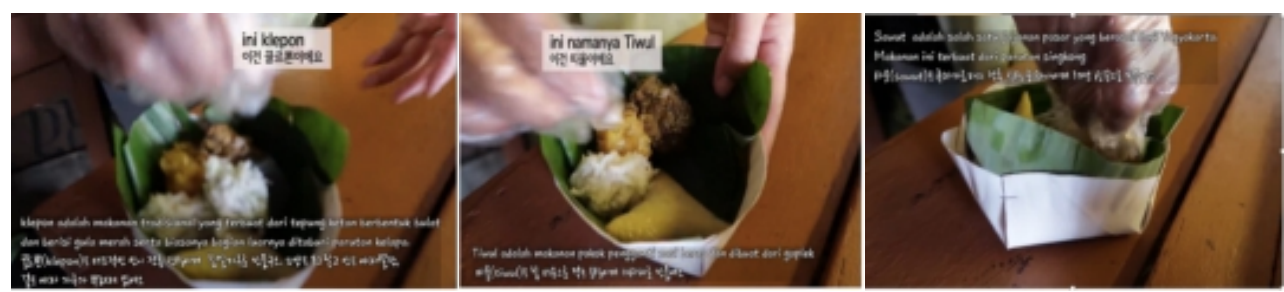

Fig. 1. Noona Rosa introduces Jajanan Pasar. Left: Klepon, Center: Tiwul, Right: Sawut (https://www.youtube.com/watch?v=YwME5oRSduE, 00:06:5-00:07:15).

Not only enriching the archipelago's culinary delights, Jajan Pasar - snacks which can be found in traditional market - such as Sawut, Tiwul and Klepon are also valued as cultural heritages that symbolize the collective identity of a group as written by Bessire [7]. From the perspective of South Koreans, Jajan Pasar looks unique because of the addition of grated coconut which is not commonly found in Korean culinary delights, and its distinctive presentation with banana leaves also adds to the Indonesian impression of this food.

Interestingly, in this video, Jajan Pasar are not found in the traditional market as it is supposed to be, but in the Museum Angkut, one of the popular tourist attractions in Batu city. This is known as cultural transformation through a revitalization process, an effort to re-explore traditional culinary delights which are now considered as cultural assets. In a postmodern perspective, the concept of "the past in the present" is a cultural phenomenon that has implications for improving social, economic and cultural life. This ultimately leads to the concept of strengthening cultural identity. So, it can be said that traditional food is able to embody local wisdom through the diet and eating habits of a community. This is in accordance with the following research results by Shah [8].

Food and identity and the process of choosing and consuming food encompasses psychological, social, economic, cultural, and biological factors, all of which play a role in the cultivation of identity surrounding consumption of food.

Not only food, places to eat are also discussed several times in the video of these South Korean YouTubers. Indonesian places to eat that are shown in their vlogs are very distinctive and local ones, such as Angkringan and street food vendors. 

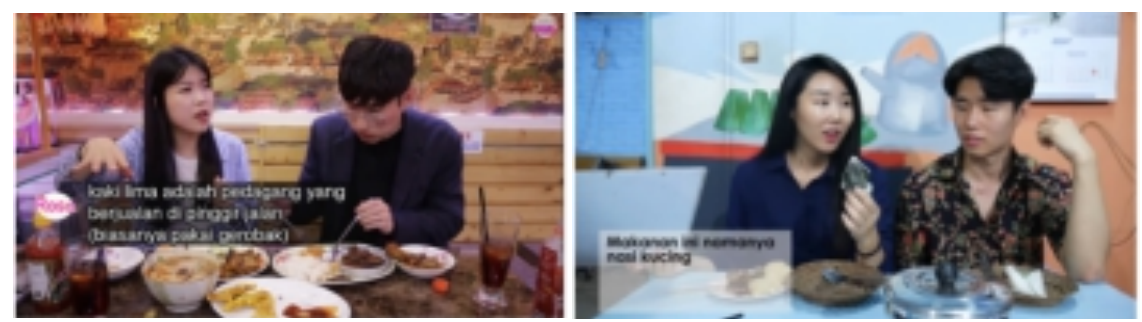

Fig. 2. Indonesian Places to eat. Left: Warung Kaki Lima, right: Angkringan (Left: https://www.youtube.com/watch?v=ntlYXVq3MK8, 00:11:12-00:11:20; Right: https://www.youtube.com/watch?v=v1XMidTOPvA, 00:01:27-00:00:29)

Pictures above are taken from two videos by two different South Korean YouTubers. The picture on the left is a video of Noona Rosa talks about her experience studies in Indonesia and discussing Warung Kaki Lima or street vendors. In the perspective of the two Koreans, the existence of street vendors is very important because it helps students who are too lazy to cook or go out to find food. Meanwhile, the picture on the left is Hari Jisun, who invites his younger brother to try to eat Nasi Kucing in Angkringan - a typical Yogyakarta street vendor which is famous for its small portions.

Food and identity expressions can be seen in the experience of eating out/buying food outside the home. Almerico [9] emphasized that "restaurants serve more than food". That is, the place to eat does not only provide food, but also "emotional needs" of customers. When someone decides to buy food out, there are many aspects that are taken into consideration, such as prestige, the comfort of the place to eat, price, menu, and so on. Local eateries offer "familiarity and authenticity in food served. For those who do not share the ethnicity of an establishment, the experience allows them to explore the novelty of a different and maybe unfamiliar culinary adventure" [9]. This can be seen in the case of the Hari Jisun video, which asserts that Nasi Kucing is a menu that not only triggers curiosity but also a sense of horror because Korean people then analogize Nasi Kucing which literally translated as cat rice with chicken rice or squid rice. At first, they thought Nasi Kucing was a rice dish with cat meat dishes, but it turned out to be packaged rice with small portions like cat food.

\section{Hari Jisun: Karena angkringan itu tidak makanan yang berat, tapi seperti dia katakan, ini makanan kecil yang dimakan sambil ngomong-ngomong. Makanan ini namanya nasi kucing, berarti nasi untuk kucing. Karena ini sedikit seperti nasi untuk kucing (Hari Jisun, 2017, 00:01:30).}

A sense of solidarity as Eastern nations can be seen from South Korea Youtubers in drawing the similarities between Indonesian dining places which are considered marginal and similar eating places in Korea. Warteg or Warung Tegal in Indonesia is not a prestigious place to eat, but it is very popular. Warteg serves home-made specialties at very affordable prices. The following quote illustrates an incident when Hari Jisun invited his mother to eat at a Warteg.

Hari Jisun: (Warteg itu) kayak 'banchanjib' (atau bekbanjib) di Korea. Pilih beberapa lauk, dan bisa bungkus sama nasi seperti itu (Hari Jisun, 2018, 00:04:43). 
Not only food and places to eat, one of the Korean YouTubers also discussed clearly the 'correct' way to enjoy certain foods and why Indonesians have the habit of using their right hand to eat. The following is one of the scenes captured in the Bandung Oppa vlog.

Bandung Oppa: Tapi kalian harus tahu ya, kalau makan di warteg harus pakai tangan kanan, karena tangan kiri dipakai untuk... begitu (Bandung Oppa, 2020 00:08:55).
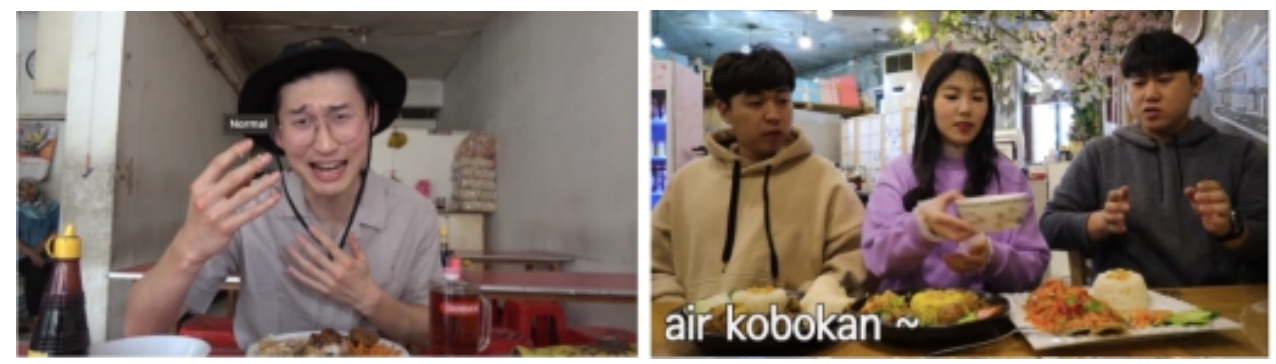

Fig. 3. Bandung Oppa and Noona Rosa demonstrate how to eat with hand (Left: https://www.youtube.com/watch?v=22zI46ytjwU, 00:08:55-00:09:07; Right: https://www.youtube.com/watch?v=22zI46ytjwU, 00:04:12-00:04:23).
Noona Rosa
: (Shows how to wash their hands in kobokan - a small bowl which contains water for washing our hands before and after having meal)
Wan
: Terus diminum?
Noona Rosa
: Ya ampun, ya gak lah.
$\mathrm{Bae}$ : Aku kira untuk minum.

(Noona Rosa, 2019, 00:04:18)

In general, Indonesians use spoons and forks to eat. However, in many areas in Indonesia, such as Java, it is common practice to eat by bare hand. More specifically, the use of the right hand to eat food is a culture adhered to by the community due to the influence of Islamic beliefs that consider the left hand as a bad or unclean hand.

\subsubsection{Javanese Language}

Javanese is known for the stratified speech words called ngoko 'low' and krama 'high' which allow speakers to show intimacy, respect and hierarchy among community members. This can be seen from the conversation between Noona Rosa (South Korean Youtuber) and online transportation driver from Malang, East Java below.

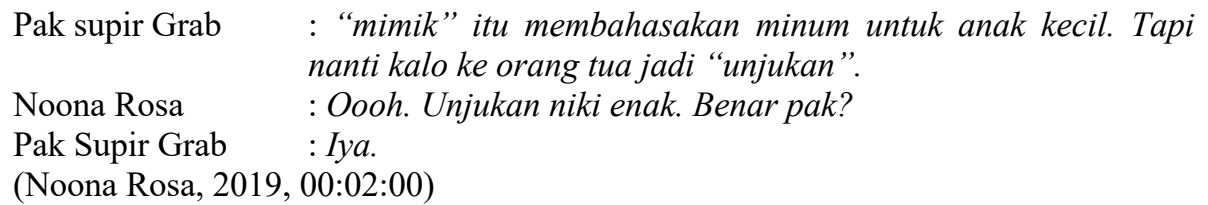


As shown in the vlog, Noona Roosa is on her way to Pecel Kawi which is said to be one of the legendary culinary spots in Malang. On that occasion, he chatted with the driver about the Javanese language used by local people. The enthusiasm and curiosity shown by Noona Rosa is seen as positive attitude because actually in terms of language and culture, both Indonesian and Korean people tend to be communal, hierarchical, formal. In South Korea, sociocultural factors - such as social strength, kinship, gender, status, occupation and age - play an important role in communication. Korean people understand politeness in language as "concept that is intricately associated with a linguistic entity known as honorifics - a system that encodes one's deference towards speaking partners who are viewed as superior in age or in social standing". The notion of honorifics in Korea is in line with the hierarchy of politeness in Javanese which is actually a 'social contract' - the recognition of the existence of the upper (superior) and lower (inferior) classes that are applied in the 'communication contract'. This means that socio-cultural factors - such as social power, kinship, gender, status, occupation, and age - play an important role in communication.

\subsubsection{Traditional Medicine}

Herbal medicine has been practiced by traditional people of Eastern countries for thousands of years, and is increasingly being used in Western countries in conjunction with or as a substitute for medical treatment. In Indonesia, herbal medicine called Jamu has been widely used to maintain health and cure diseases since centuries ago. The Vlogs of the South Korean YouTubers also portray traditional Indonesian medicine which was considered unique and an attraction in learning Indonesian culture. In one of his vlogs, Bandung Oppa and one of his Korean friends tried to drink Jamu and gave the following comments:

$\begin{array}{ll}\text { Bandung Oppa } & \text { : Bisa dibilang, ini minuman yang terbuat dari jahe. Ini juga } \\ & \text { diminum saat kita merasakan kedinginan. } \\ \text { Jihyeok } & \text { : Sungguh? } \\ \text { Bandung Oppa } & \text { : Tubuh kita akan jadi hangat. Kita akan tahu jika meminumnya. } \\ \text { Bandung Oppa } & \text { : Ini rasa yang biasa diminum orang tua di Korea. } \\ \text { Bandung Oppa } & \text { : Sekali lagi, Indonesia adalah negara rempah-rempah. Ada } \\ & \text { berbagai macam rempah-rempah yang ada dalam minuman } \\ & \text { seperti ini (merujuk ke jamu). } \\ \text { Bandung Oppa } & \text { : Aku merasa kagum saat ada minuman seperti ini. } \\ \text { (Bandung Oppa, 2019,00:02:51) }\end{array}$

By promoting Indonesian traditional medicine and ingredients in their vlog, these Korean YouTubers want to provide another perspective on how a community maintains its health. This traditional herbal medicine (Jamu) reflects local wisdom because it originates from the culture and life of people from ancient times who embody human life and death as a natural cycle of life that synergizes with natural and universal energy. Furthermore, it can be concluded that this vlog intends to oppose the superiority of western medicine. This idea is in line with the conclusions of Yuen, Sonny and Yung [10] research as follows:

"Western medicine has a single-minded, materialistic approach that, basically, reduces all bodily function and dysfunction to material causes, mechanical mechanisms and structural flaws that can be thought of and studied in isolation from 
those who suffer from them - the so called 'science', which relies on objective, demonstrable, measurable, and self-evident observations".

\subsubsection{System in the Society}

Even though South Korea and Indonesia are both eastern countries, they practically have different society systems. Those differences may cause culture shock when Koreans visit Indonesia for the first time or vice versa. The first system mentioned here is wedding ceremony. As stated by Bandung Oppa in his video (Bandung Oppa, 2020), he respected Indonesians that still follow their own traditional culture during wedding ceremony. He also showed his regret that South Koreans nowadays prefer Western style wedding more than their own traditional one, since they think that Western style wedding looks more modern. Here, Bandung Oppa as someone from Eastern country just stated that Indonesia, as an Eastern country, still being "a place where family values, tradition, spirituality, morality, and hard work are valued" [11].

The second one is about what Indonesians call Banci, or drag queen, which is not something familiar for Koreans. In a collaborative video between Bandung Oppa and Noona Rosa, they talked about these phenomena, and instead of giving negative remark about those people that they accidentally meet quite often, Noona Rosa said that they were not only kind people but also funny in their own way (Bandung Oppa, 2019).

Here, cultural proximity is an aspect that they brought out to talk about this issue. Instead of talking about negative thing, they talked more about the similarities found in both countries, even though still they listed some differences.

The next thing discussed about this issue is transportation system. Bandung Oppa and his friend, Dongho, talked about online transportation in Indonesia which helps people's high mobility in this era, (Bandung Oppa, 2019). Nevertheless, they also identified that drivers in Indonesia do not really respect the pedestrians, which is a dangerous thing to do.

The last thing discussed is about halal food, which is normal in Indonesia since most of Indonesians are Moslems. In one of her videos, Hari Jisun tried to buy some food in a certain Korean food restaurant in Indonesia. Since there were many questions asked about whether the products are halal or not, she tried to find the answer by confirming to the restaurant owner.

Hari Jisun: Banyak viewer tanya seperti "Kalau ke restoran Korea aku agak khawatir kalau makanan Korea disana mengandung haram, gimana ya?" seperti itu. Tapi aku sudah tanya kepada sajangnim, di sini katanya ada dua jenis mеnu. Menu untuk orang korea dan menu untuk orang Indonesia. Kalau menu untuk orang Indonesia benar-benar tidak mengandung bahan-bahan yang haram dan tempat masak juga beda jadi tidak usah khawatir (Hari Jisun, 2018, 00:02:28).

What Hari Jisun did here show that even though Indonesians tend to adapt culture from other countries, those cultural products are still localized through many ways, to adapt with Indonesian's value. Related with Korean food in Indonesia, many Indonesians love to consume them, both because they want to identify themselves as hallyu fans by consuming something iconic, and the foreignness aspect in those culinary products. 


\subsubsection{Work Ethic}

Through his video, Bandung Oppa stressed that Eastern is "a place where family values, tradition, spirituality, morality, and hard work are valued" [11]. People from Eastern really highly value the importance of their family values, their cultural traditions, spirituality, morality, and a great work ethic where people work hard to reach their goals. Nevertheless, this kind of quality was stressed more on Koreans rather than Indonesians.

\section{Bandung Oppa: Sebenarnya, di Bandung saya agak kaget. Di dalam mall ada pegawai (beberapa) yang main hp. Menurut saya, itu juga agak culture shock. Kalau di Korea, pegawainya pasti sangat rajin, maksudnya tidak bisa main hp dan fokus pada kerja. Tapi di Indonesia saya mengalami, orangnya sangat santai (Bandung Oppa, 2019, 00:05:33).}

What Bandung Oppa did here is a process that Huat and Iwabuchi $(2008,79)$ called as identification and distancing, a term used to call audiences of an Asian television programs from other Asian country. In this case, Bandung Oppa identified Eastern work ethic as something familiar, but he also mentioned about foreignness aspect, in which work ethic in Indonesia is far different from the one in South Korea.

By analyzing those narrations, those Korean Youtubers participate in a process that is called decolonization, which according to Griffiths et al. [12] is "a radical dismantling of the European codes and post-colonial subversion and appropriation of the dominant European discourses". In other words, to show others about their own identity and to erase the traces of domination as result of Western invasion, they do it by involving other subordinated Eastern country.

\subsection{Youtubers, Fans and Covid-19}

Started from Wuhan, Covid-19 is now spread to many countries around the world, including both Indonesia and South Korea. People are forced to practice a better healthy life and be extra careful, although somehow people slowly become reckless and careless. This is where those Youtubers play a very significant role to remind people that this pandemic is not over yet, that they should stay alert and do their best.

It is already known that audiences are never passive. Audiences are active participants that produce their own meanings about the things that they consume, just as what Fiske [2] stated, "The moment of reading is when the discourses of the reader meet the discourses of the text".

Related to Fiske's theory of intertextuality, the videos uploaded by those Youtubers are the secondary texts, while the audiences' comments related to those videos are seen as tertiary texts. According to Fiske [2] "secondary texts play a significant role in influencing which of television's meanings may be activated in any one reading”. Bandung Oppa, Noona Rosa and Hari Jisun show how important it is to always wash our hands or wear facemask every time we want to go some places when they promote Indonesian local culture in their videos. While mainly still talk about Indonesian culture or Indonesians' way of life, they still remind the fans or their audiences that due to Covid 19 we need to change our habits. On the other hand, Bandung Oppa created some videos that particularly talk about Covid-19. In one of his videos, he created a video specially for comparing how Indonesian and Korean systems in preventing Covid-19, so that Indonesians may learn something useful there. Those kinds of videos will 
slowly affect their fans, who will do the exact Covid-19 prevention to identify themselves with their idols.

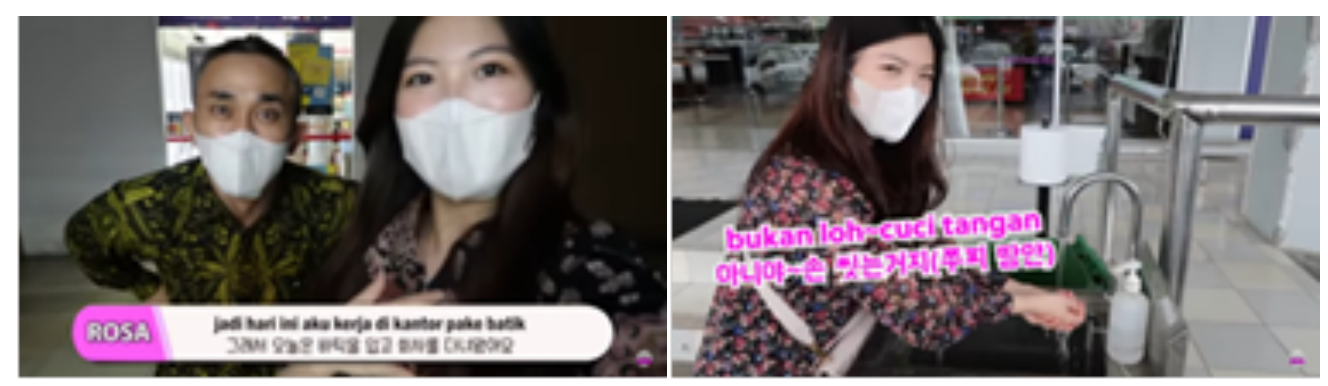

Fig. 4. Left: Noona Rosa shows how it is obliged to wear facemask outside. Right: Noona Rosa washes her hands after doing her business outside (https://www.youtube.com/watch?v=ug534jHeCrM, Left: 00:00:09 Right: 00:02:32).

Moreover, analyzing the comments in the videos related with those protocol is crucial, since comments show how much the meaning is interpreted by audiences. Most comments are showing positive attitudes from the viewers, especially for videos created mainly for talking about Covid-19, although not many comments - specifically for videos that focused on Indonesian culture more -- related with Covid-19 preventions are expressed there.

\section{Conclusion}

From the analysis, it can be concluded that Indonesia and South Korea are having cultural proximity, where both own quite various unique local cultures but still they have their own values related to that. By applying self-orientalism theory, it is concluded that those three Youtubers - who talk about traditional food, language, work ethics, social systems and others still giving positive reviews about Indonesia even though they still think that some aspects are lacking, where South Korea's system is better in those fields. These phenomena may happen because both Indonesia and South Korea are Eastern countries that understand about each other's values, that they need to show it through their own point of view instead of from what Western already picturized about them or Eastern in general.

By applying intertextuality to see their contributions in preventing the spread of Covid-19, we can see how they play significant role in this matter. Not only they talk about how to live a healthy life by giving hints here and there, but also, they upload some videos specially made to talk about Covid-19. They talk about that because Covid-19 cases are quite threatening and worrying, which make it important to emphasize that we really need to change our way of life to make the situation better, and the positive comments that the audiences gave are parts of the prove that it is quite effective.

For the next researchers, it is recommended to apply other theories such as post colonialism, Occidentalism or orientalism to do similar research. This way, we may see how Western people nowadays see Eastern cultures, or how Eastern Youtubers see Western cultures and values these days, whether their stereotype is still the same or whether they already have new insights. It is also recommended to analyze how Indonesian Youtubers see other countries through their point of view, to analyze how they see others' cultures and values. 


\section{References}

[1] M. J. Stiffler, "Consuming Orientalism: Public Foodways of Arab American Christians," Mashriq Mahjar J. Middle East North African Migr. Stud., vol. 2, no. 2, 2014.

[2] J. Fiske, Television culture. Routledge, 2010.

[3] B. H. Chua and K. Iwabuchi, East Asian pop culture: Analysing the Korean wave, vol. 1. Hong Kong University Press, 2008.

[4] S. Cheng, "Cultural Proximity, Diasporic Identities, and Popular Symbolic Capital: Taiwan Cultural Worker Qiong Yao's Cultural Production in the Chinese Media Market'," Glob. Media $J$, vol. 5, no. 8, pp. 1-19, 2006.

[5] S. Bozdogan, "Orientalism and architectural culture," Soc. Sci., pp. 46-58, 1986.

[6] G. Fischer, K. Frohberg, M. A. Keyzer, and K. S. Parikh, Linked national models: A tool for international food policy analysis. Springer Science \& Business Media, 1988.

[7] J. Bessière, "Local development and heritage: traditional food and cuisine as tourist attractions in rural areas," Sociol. Ruralis, vol. 38, no. 1, pp. 21-34, 1998.

[8] R. Shah, "Food \& Identity: Food Studies, Cultural \& Personal Identity," 2018.

[9] G. M. Almerico, "Food and identity: Food studies, cultural, and personal identity," J. Int. Bus. Cult. Stud., vol. 8, p. 1, 2014.

[10] J. W. M. Yuen, H. M. Sonny, and J. Y. K. Yung, "Traditional chinese herbal medicine-east meets west in validation and therapeutic application," Recent Adv. Theor. Pract. chinese Med., vol. 239, 2012.

[11] S. Kerboua, "From Orientalism to neo-Orientalism: Early and contemporary constructions of Islam and the Muslim world," Intellect. Discourse, vol. 24, no. 1, 2016.

[12] G. Griffiths, W. Ashcroft, and F. M. Ashcroft, The post-colonial studies reader. Psychology Press, 1995. 